\title{
Bilateral inflammatory aural polyps in a kitten - case report
}

\author{
Pólipo aural inflamatório bilateral em um filhote de gato - relato de caso \\ Cristiane Bazaga Botelho (iD, Rafaella Tortoriello Barbosa Sampaio (D), \\ Natália Lôres Lopes² ${ }^{10}$, Julio Israel Fernandes ${ }^{3}$ (1)
}

\begin{abstract}
Feline aural inflammatory polyps are non-neoplastic masses in the tympanic cavity or the Eustachian tube that can be observed in the ear canal of the cat and are a common cause of otitis externa and otitis media in young animals, with or without respiratory signs depending on the direction of polyp growth. Most of the polyps occurring in cats are unilateral. Otoscopy or video-otoscopy is necessary for its diagnosis, and treatment consists of the mechanical removal of the polyp and subsequent use of anti-inflammatory drugs. The aim of this paper was to report a case of bilateral inflammatory aural polyps in a kitten treated successfully by the minimally invasive technique of per-endoscopic trans-tympanic traction. A seven-monthold female mixed-breed cat, presenting bilateral ear discharge, was submitted to endoscopic examination of both ears and polypoid masses observed in each horizontal canal. Both polyps were grasped and pulled with a polypectomy snare through the otoendoscope. The patient received dexamethasone immediately after the procedure and a long-term oral corticosteroid protocol was established post-avulsion. It was concluded that otoendoscopy allowed an accurate and quick diagnosis, that the mass removal by per-endoscopic trans-tympanic traction was an effective treatment with no complications, and that bilateral occurrences could indicate a differential diagnosis, especially in young cats.
\end{abstract}

KEYWORDS: Cat; Otitis; Otoendoscopy; Feline.

RESUMO: Pólipos inflamatórios aurais felinos são massas não neoplásicas na cavidade timpânica ou na tuba auditiva que podem ser observadas no canal auditivo do gato e são uma causa comum de otite externa e otite média em animais jovens, com ou sem sinais respiratórios dependendo da direção do crescimento do pólipo. A maioria dos pólipos que ocorrem em gatos é unilateral. A otoscopia ou vídeo-otoscopia é necessária para o seu diagnóstico, e o tratamento consiste na remoção mecânica do pólipo e posterior uso de anti-inflamatórios. O objetivo deste trabalho foi relatar um caso de pólipos aurais inflamatórios bilaterais em um felino filhote tratado com sucesso pela técnica minimamente invasiva de traçáo trans-timpânica perendoscópica. Um felino fêmea de sete meses de idade, sem raça definida, apresentando secreção auricular bilateral, foi submetido a exame endoscópico de ambas as orelhas e massas polipóides foram observadas em cada canal horizontal. Ambos os pólipos foram apreendidos e puxados com uma alça de polipectomia através do otoendoscópio. O paciente recebeu dexametasona imediatamente após o procedimento e um protocolo de corticosteroide oral em longo prazo foi estabelecido após a avulsão. Concluiu-se que a otoendoscopia permitiu um diagnóstico preciso e rápido, que a retirada das massas por tração transtimpânica perendoscópica foi um tratamento eficaz e sem complicaçóes e que as ocorrências bilaterais podem indicar um diagnóstico diferencial, principalmente em gatos jovens.

PALAVRAS- CHAVE: Gato; Otite; Otoendoscopia; Felino.

\section{INTRODUCTION}

Feline inflammatory polyps are characterized as non-neoplastic masses that can be observed in the ear canal or nasopharynx (MILLER; GRIFFIN; CAMPBELL, 2012; GRECI; MORTELLARO, 2016). Although their etiology is unknown, polyps may be correlated to abnormal inflammatory reaction to the commensal nasopharyngeal microflora and virus infections in the respiratory tract (NUTTALL, 2020). A recent study analyzed tissues from feline calicivirus and herpesvirus-1 polyps and hypothesized that these viruses are not associated to inflammatory polyps or that viral persistence is not required for the perpetuation of the inflammation (VEIR et al., 2002).

\footnotetext{
'Veterinary, MSc, Doctoral Student. Programa de Pós-Graduação em Ciências Veterinárias, Instituto de Veterinária, Universidade Federal Rural do Rio de Janeiro - UFRRJ, Seropédica, RJ, Brasil.

Veterinary, MSc, Doctoral Student. Programa de Pós-Graduação em Medicina Veterinária, Instituto de Veterinária, Universidade Federal Rural do Rio de Janeiro - UFRRJ, Seropédica, RJ, Brasil.

${ }^{3}$ Veterinary, DSc. Departamento de Medicina e Cirurgia Veterinária, Instituto de Veterinária, Universidade Federal Rural do Rio de Janeiro - UFRRJ, Seropédica, RJ, Brasil. *Corresponding author: rafaellatortoriello@hotmail.com

Received: 09/04/2021. Accepted: 16/05/2021
} 
Cats can be more affected than dogs (MILLER; GRIFFIN; CAMPBELL, 2012) and the condition is more observed in young cats (NUTTALL, 2020) with an average age of onset reported as 5.1 years, varying from $0.25-18$ years (VEIR et al., 2002). Indeed, some authors observed an average age of 2 years, ranging from 4 months to 16 years (HOPPERS; MAY; FRANK, 2020). Difference in the prevalence between males and females is not observed (VEIR et al., 2002; GRECI; VERNIA; MORTELLARO, 2014; HOPPERS; MAY; FRANK, 2020). Although no breed predilection is observed (VEIR et al., 2002), domestic short-hair cats were the breed most reported by other authors (GRECI; VERNIA; MORTELLARO, 2014; HOPPERS; MAY; FRANK, 2020).

Most of the polyps occurring in cats are unilateral (MILLER; GRIFFIN; CAMPBELL, 2012; NUTTALL, 2020), although bilateral polyps have a prevalence rate of $24 \%$ (HOPPERS; MAY; FRANK, 2020). Inflammatory polyps are a common cause of otitis in cats (NUTTALL, 2020) but upper respiratory disease can also occur (MILLER JR; GRIFFIN; CAMPBELL, 2012). Some animals show a combination of respiratory and otic signs, this being observed in $29 \%$ of cats, while $50 \%$ had otic signs alone (VEIR et al., 2002). Otitis media and/or externa may be present and clinical signs such as otic discharge, headshaking and aural pruritus are observed (MILLER; GRIFFIN; CAMPBELL, 2012; GRECI; VERNIA; MORTELLARO, 2014; NUTTALL, 2020). Furthermore, neurological signs such as head tilt, Horner's syndrome, facial nerve paralysis and nystagmus may occur (MILLER; GRIFFIN; CAMPBELL, 2012; GRECI; VERNIA; MORTELLARO, 2014). Respiratory signs such as sneezing, coughing, congestion and dyspnea are also described (HOPPERS; MAY; FRANK, 2020). An atypical clinical manifestation of secondary pulmonary hypertension has been reported (MACPHAIL et al., 2007).

To achieve the diagnosis, in most cases otoscopy or videootoscopy is necessary to see the polyps but, in some cases, at least one imaging examination is required to confirm the presence (GRECI; MORTELLARO, 2016; JANSSENS; HAAGSMAN; HAAR, 2017). Conventional radiology may be a hypothesis, but it is already known that it is not an ideal examination (LANE et al., 1981; ANDERSON; ROBINSON; WHITE, 2000), mainly because it requires general anesthesia, at least three projections and, in many cases, the use of contrasts, with limited improvement in image quality (KUDNIG, 2002; BISCHOFF; KNELLER, 2004; GRECI; MORTELLARO, 2016). Computed tomography (CT) allows an accurate and detailed evaluation of all segments of the ear (external, middle, and internal parts) and nasopharynx (ANDERS et al., 2008; GRECI; MORTELLARO, 2016; JANSSENS; HAAGSMAN; TER HAAR, 2017; BOTELHO, 2019). Because of these and other benefits, CT is currently considered a better option for imaging examination, therefore improving the diagnosis, mainly of challenging clinical conditions (KUDNIG, 2002; MACPHAIL et al.,
2007; GRECI; MORTELLARO, 2016; HOPPERS; MAY; FRANK, 2020). Another examination that can be employed is magnetic resonance imaging (MRI), but it also has limitations, particularly high cost (BISCHOFF; KNELLER, 2004; GRECI; MORTELLARO, 2016).

Otoendoscopy or video-otoscopy can diagnose aural polyps in the external auditory canal as well as the tympanic cavity. This procedure also makes possible evaluation of the tympanic membrane. Its evaluation is of great relevance, since opacity and thickening may indicate the existence of polyps in the middle ear causing otitis media (GRECI; VERNIA; MORTELLARO, 2014; GRECI; MORTELLARO, 2016; HOPPERS; MAY; FRANK, 2020). In spite of all the imaging examinations previously mentioned, the definitive diagnosis will always be established through histopathological analysis of a sample (MACPHAIL et al., 2007; HOPPERS; MAY; FRANK, 2020). The treatment consists of the mechanical removal of the polyp with subsequent use of anti-inflammatory drugs, associated or not with antibiotics, both systematically and/or topically (VEIR et al., 2002; DONNELLY; TILLSON, 2004; GRECI; VERNIA; MORTELLARO, 2014; NUTTALL, 2020). Polypectomy can be performed surgically, using techniques such as ventral bulla osteotomy, traction after vertical ear canal incision, or total or partial ablation of the auditory canal (GRECI; MORTELLARO, 2016; KOCH, 2016; MARTINS, 2019; NUTTALL, 2020). The first two techniques are still widely used; however, these can cause complications (KUDNIG, 2002; VEIR et al., 2002) such as damage to the facial nerve, sympathetic trunk, and vestibular apparatus (KUDNIG, 2002). Nowadays, with the advances in veterinary medicine, endoscopy techniques are used increasingly (MCKEEVER; TORRES, 1997; DONNELLY; TILLSON, 2004; GRECI; VERNIA; MORTELLARO, 2014; GRECI; MORTELLARO, 2016) and per-endoscopic trans-tympanic traction, a technique very little known in Brazil, has been shown to be of great value, given its minimally invasive character, short anesthetic and surgical time, and excellent recovery with fewer complications in the post-surgical period (GRECI; VERNIA; MORTELLARO, 2014).

The aim of this study was to report a case of bilateral inflammatory aural polyp in a feline treated successfully by the minimally invasive technique of per-endoscopic transtympanic traction.

\section{CASE REPORT}

A seven-month-old female mixed-breed cat, weighing $2.7 \mathrm{~kg}$, was referred to a veterinary dermatologist in Rio de Janeiro, Brazil by her veterinary physician. The cat was fostered when it was 4 months old and had a history of bilateral ear discharge from 2 months old, with mild otic pruritus and head shake. It was prescribed several topic treatments by the cat's veterinary physician, including treatments for Otodectes cynotis and 
fungal infection, with very low benefit. The cat's owner mentioned that no otoscopic examination or cytological examination had been performed prior to referral to the veterinary specialist. The animal showed good physical health, had been given all the vaccines, was fed with good cat food and had free access to outdoors. The animal's physiological parameters were normal for the species. Ear examination showed no lesions to the pinna but an important bilateral purulent discharge and images of likely masses on both external canals when examined by otoscope (Figure 1).

The cat presented clinical signs of otitis externa on both ears with intense pruritus and some discomfort during the otoscopic examination. No neurological signs were presented. Ear exudate was collected from both ears using a sterile swab for cytology analysis, which showed the presence of uncountable cocci in both samples.

To confirm the presence of the masses, the animal was submitted to flushing of both ears to clean the ear canal, under anesthesia, with a warn $0.9 \%$ saline solution under video-otoscopy (MDS - Vet endoscopes) evaluation. It was then confirmed that there were polypoid masses in each horizontal canal. Both polyps were then grasped and pulled with a polypectomy snare $(5 \mathrm{Fr}$., length $32 \mathrm{~cm}$ ) through the otoendoscope and came out completely from both ears. Then, both external and middle ears were flushed with warm $0.9 \%$ saline solution through the ruptured tympanic membrane to clean any remaining secretion and to control the bleeding. It is important to highlight that blood tests were performed prior to surgery, where no changes in blood count or platelets were observed. Therefore, there was no risk of hemorrhage, according to the insignificant volume of blood lost, and hemostasis is controlled physiologically in healthy patients.
All procedures were carried out by a trained and experienced veterinary dermatologist.

The cat received only dexamethasone $0.2 \mathrm{mg} / \mathrm{kg}$ IV after the procedure, yet pain medication was not necessary. It is worth mentioning that at the time of the polyp's avulsion, the animal was anesthetized, that the procedure was considered minimally invasive and that its postoperative period was considered painless. Furthermore, according to Canfield and Rosychuk (2018), in most cases analgesic therapy is not recommended, either in the trans-surgical or in the postoperative period. The samples collected were submitted in buffered formalin $10 \%$ for histopathological analysis, which showed a polypoid nodule covered by ciliated epithelium (the type of epithelium seen in the middle ear, so confirming its origin) constituted by collagenous tissue diffusely compromised by inflammatory infiltrate rich in plasmocytes and lymphocytes and the presence of scarce ceruminous glands differentiated in the right ear. Histological examination of the left ear showed polypoid nodules widely ulcerated with edema and moderate neovascularization or covered by ciliated epithelium with goblet cells or non-keratinized squamous cells, consisting of dense to slightly edematous collagenous tissue with the presence of some ceruminous glands well differentiated from cystic. A moderate-to-marked mixed inflammatory infiltrate was observed with a predominance of plasma cells and lymphocytes or neutrophils under the ulcer. A long-term oral corticosteroid protocol was established post-avulsion, so the cat was treated with oral prednisolone, beginning at $2 \mathrm{mg} / \mathrm{kg} /$ day for 2 weeks, followed by $1 \mathrm{mg} / \mathrm{kg} / \mathrm{day}$ for 2 weeks, $0.5 \mathrm{mg} / \mathrm{kg} /$ day for 2 weeks, and $0.5 \mathrm{mg} / \mathrm{kg}$ once every other day for 2 weeks ( 8 weeks of therapy). Topical eye drops containing dexamethasone

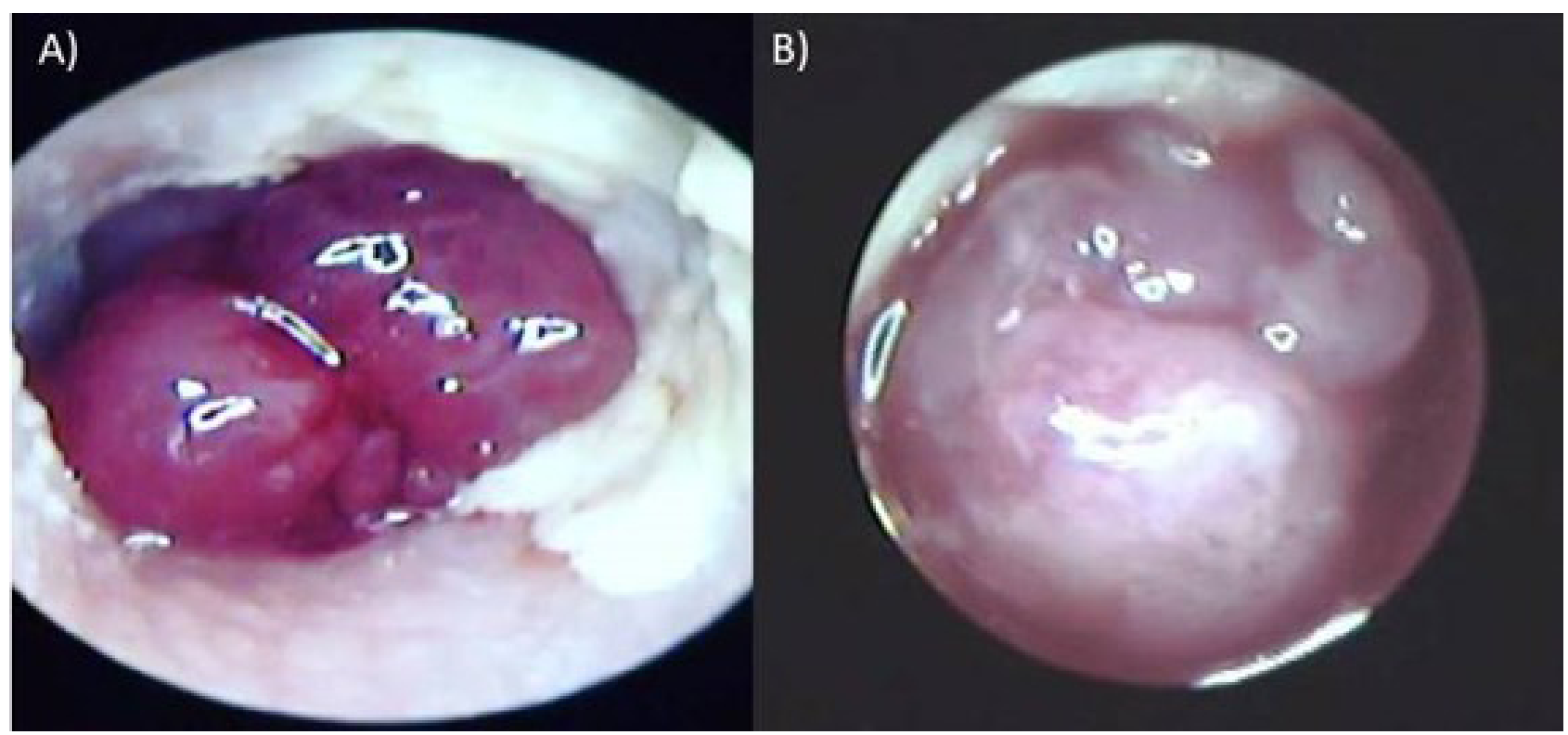

Figure 1. Otoscope appearance of a feline aural inflammatory polyp on both external canals: a) Polyp present in the right ear; note the evident erythematous aspect, and b) Polyp present in the left ear; note the existence of associated serosanguineous secretion. 
$0.1 \%$, with ciprofloxacin hydrochloride $0.35 \%$ were added to the protocol, every 12 hours for 3 weeks. The therapeutic protocol described above follows the guidelines recommended by Canfield and Rosychuk (2018) which associates the administration of oral glucocorticoids with a high success rate and a $95 \%$ reduction in recurrence.

Short-term outcome was assessed by clinical re-examination with help of video-otoscopy at 1 and 2 months after the procedure. The presence of an intact, but opaque, ear drum after the procedure was observed and considered a normal finding at re-examination because it is part of the healing process after rupture. The cat presented no clinical sign of otitis externa or otic discharge. After two years, the animal still shows no clinical sign of otitis externa and is free of any otic discharge or discomfort. Indeed, the tympanic membranes are intact and normal when assessed by video-otoscopy.

\section{DISCUSSION}

According to several authors, unilateral polyps are the most prevalent non-neoplastic masses in young cats causing otitis externa (LANE et al., 1981; GRECI; MORTELLARO, 2016; JANSSENS; HAAGSMAN; TER HAAR, 2017). This case report describes a bilateral involvement confirmed by histopathological analysis. Corroborating with predisposition and symptoms already described in previous studies, the patient was a young feline presenting bilateral otitis externa (MILLER; GRIFFIN; CAMPBELL, 2012; GRECI; VERNIA; MORTELLARO, 2014; NUTTALL, 2020); in other words, fitting the $50 \%$ of cases that do not show neurological symptoms (VEIR et al., 2002). The etiology of inflammatory polyps is still unknown; however, the involvement of inflammatory processes in the commensal nasopharyngeal microflora is one of the factors correlated to their appearance (GRECI; VERNIA; MORTELLARO, 2014; NUTTALL, 2020). It is worth highlighting that in the history mentioned above the patient had shown bilateral ear discharge from 2 months old. As the clinical evaluation was carried out only a few months later, it can be questioned whether the animal already had the masses at the time of the first signs or whether the chronic inflammation had triggered the excess of cerumen and the further development of polyps. The authors agree that the bilateral ear discharge previously reported was due to the presence of polyps because, as reported by Miller, Griffin and Campbell (2012), Harvey and Paterson (2014) and Nuttall (2020) otitis externa in companion animals can be classified as a primary, secondary, predisposing or perpetuating factor. The animal had been treated for ear mites, and this is the main cause of primary otitis in this species and also of malassezia otitis, which is classified as due to secondary causes, thus occurring more frequently in endocrinopaths, allergists, seborrheic animals and in Persians due to a racial predisposing factor. That is, the reinfection of the animal in question, triggered in a short period of time in a mixed-breed animal without associated cutaneous symptoms and at an unusual age for the triggering of hormonal or allergic diseases, together with the subsequent improvement after the removal of the polyp, leads to the conclusion that the episodes of otitis at 2 months of age had developed due to a perpetuating factor such as the existence of polyps.

Another interesting point in this case was the existence of bacterial external otitis and the question of whether the existence of these microorganisms was able to trigger the inflammatory process, and consecutively the polyp, even with no previous history of upper respiratory infection, or whether their presence was secondary to the perpetuation of the obstructive condition. However, in agreement with previous studies, despite the existence of these bilateral polyps, they did not cause worsening of symptoms when compared to cases presenting unilateral polyps (HOPPERS; MAY; FRANK, 2020).

Therefore, the facts pointed out above makes evident the importance of an accurate diagnosis and, as proposed by Greci, Vernia and Mortellaro (2014), for the patient in question there was no need to perform radiography or CT, only video-otoscopy and ear flushing under anesthesia for the correct confirmation of bilateral polyp. However, in some cases it may be necessary to perform more imaging examinations to differentiate dense masses from fluid structures or bone changes, this being a limitation of the video-otoscopy technique. However, when possible, the performance of otoendoscopy alone has the advantage of making possible the simultaneous diagnosis and treatment by trans-tympanic traction.

Perendoscopic trans-tympanic traction has been proved to be an excellent technique, as comparing the results found in this case with those cited by Greci, Vernia and Mortellaro (2014), an exceptional post-procedure recovery was obtained without complications or neurological signs that could be observed in cats immediately after treatment. The opaque ear drum observed has been reported by other authors in cats with short-term outcomes considered excellent (GRECI; VERNIA; MORTELLARO, 2014). In fact, this technique still has the advantages of reduced surgical time and low cost.

A current survey reports bilateral involvement in 24\% of patients (HOPPERS; MAY; FRANK, 2020); not as infrequent as proposed in previous studies (MILLER; GRIFFIN; CAMPBELL, 2012; NUTTALL, 2020), but the existence of bilateral polyps does not seem to be a predisposing factor for recurrence when compared to unilateral polyps. This correlates with the satisfactory result of the present report, since, after two years, the animal still shows no clinical signs of the return of polyps or otitis externa and is free of any otic secretion or discomfort. However, the technique used to remove the polyps has shown less incidence compared to other methods (GRECI; VERNIA; MORTELLARO, 2014; HOPPERS; MAY; FRANK, 2020). In fact, especially in bilateral conditions in a young animal, one should always opt for less aggressive 
techniques with less chance of relapse, given the importance of this patient's future quality of life.

\section{CONCLUSION}

Otoendoscopy allowed an accurate and quick diagnosis, and the mass removal by per-endoscopic trans-tympanic traction was an effective non-invasive treatment with no complications. As we know, inflammatory aural polyps are very common in cats, but bilateral occurrences are uncommon and underreported and could indicate a differential diagnosis, especially in young cats.

\section{ACKNOWLEDGMENTS}

To Fundação de Amparo à Pesquisa do Estado do Rio de Janeiro (FAPERJ) for funding this study. This study was financed in part by Coordenação de Aperfeiçoamento de Pessoal de Nivel Superior-Brasil (CAPES).

\section{REFERENCES}

ANDERS, B B. et al. Analysis of auditory and neurologic effects associated with ventral bulla osteotomy for removal of inflammatory polyps or nasopharyngeal masses in cats. Journal of the American Veterinary Medical Association, [S. I.], v. 233, n. 4, p. 580-585, 2008. DOI: 10.2460/javma.233.4.580.

ANDERSON, D. M.; ROBINSON, R. K.; WHITE, R. A. S. Management of inflammatory polyps in 37 cats. Veterinary Record, [S. I.], v. 147, n. 24, p. 684-687, 2000. DOI: 10.1136/vr.147.24.684.

BISCHOFF, M G.; KNELLER, S K. Diagnostic imaging of the canine and feline ear. Veterinary Clinics of North America - Small Animal Practice, [S. I.], v. 34, n. 2, p. 437-458, 2004. DOI: 10.1016/j. cvsm.2003.10.013.

BOTELHO, D. M. P.. Estudo retrospetivo de massas nasofaríngeas e/ou auditivas no gato: padrões imagiológicos em TC e respetiva caracterização histopatológica. 2019. (tese de doutorado). Universidade de Lisboa, Faculdade de Medicina Veterinária.

DONNELLY, KE.; TILLSON, D. M. Feline inflammatory polyps and ventral bulla osteotomy. Compendium on continuing education for the practising veterinarian-north american edition-.., [S. I.], v. 26, n. 6, p. 446-455, 2004.

GRECI, V; MORTELLARO, C. M. Management of Otic and Nasopharyngeal, and Nasal Polyps in Cats and Dogs. Veterinary Clinics of North America - Small Animal Practice, [S. I.], v. 46, n. 4, p. 643-661, 2016. DOl:10.1016/j.cvsm.2016.01.004. Disponível em: http:/dx.doi.org/10.1016/j.cvsm.2016.01.004.

GRECI, V; VERNIA, E; MORTELLARO, C. Per-endoscopic trans-tympanic traction for the management of feline aural inflammatory polyps: A case review of 37 cats. Journal of Feline Medicine and Surgery, [S. I.], v. 16, n. 8, p. 645-650, 2014. DOI: 10.1177/1098612X13516620.

HARVEY RG, PATERSON S. Otitis externa: an essential guide to diagnosis and treatment. Boca Raton: CRC Press; 2014.

HOPPERS, S. E.; MAY, E. R.; FRANK, L. A. Feline bilateral inflammatory aural polyps: a descriptive retrospective study. Veterinary Dermatology, [S. I.], v.300, p.299-300,2020.DOl:10.1lll/vde.12877.
JANSSENS, S. D. S.; HAAGSMAN. AN.; TER HAAR. Middle ear polyps: results of traction avulsion after a lateral approach to the ear canal in 62 cats (2004-2014). Journal of Feline Medicine and Surgery, [S. I.], v. 19, n. 8, p. 803-808, 2017. DOI: 10.1177/1098612X16660356.

KOCH, S. N. Feline otitis: diagnosis and treatment. In: SPONSORS OF THE 8 TH WORLD CONGRESS OFVETERINARY DERMATOLOGY 2016, Bordeaux. Anais [...]. [s.l: s.n.] p. 230.

KUDNIG, S. T. Nasopharyngeal polyps in cats. Clinical techniques in small animal practice, [S. I.], v. 17, n. 4, p. 174-177, 2002. DOI: 10.1053/svms.2002.36602.

LANE, J. G. et al. Nasopharyngeal polyps arising in the middle ear of the cat. Journal of Small Animal Practice, [S. I.], v. 22, n. 8, p. 5ll-522, 1981. DOI: 10.11ll/j.1748-5827.1981.tb00638.x.

MACPHAIL, C. M. et al. Atypical manifestations offeline inflammatory polyps in three cats. Journal of Feline Medicine and Surgery, [S. I. ], v. 9, n. 3, p. 219-225, 2007. DOI: 10.1016/j.jfms.2006.11.004.

MARTINS, F. G. V. O. Osteotomia ventral da bula timpânica em gatos com massas polipoides: estudo retrospetivo, 12 casos. 2019. (Tese de doutorado). Universidade de Lisboa, Faculdade de Medicina Veterinária, , .

MCKEEVER, P.J.; TORRES, S. M. F. Ear disease and its management. Veterinary Clinics of North America - Small Animal Practice, [S. I.], v. 27, n. 6, p. 1523-1536, 1997. DOI: 10.1016/S0195-5616(97)501379. Disponível em: http:/dx.doi.org/10.1016/S0195-5616(97)50137-9.

MILLER JR, W. H.; GRIFFIN, C. E.; CAMPBELL, K. L. Muller and Kirk's small animal dermatology. Diseases of Eyelids, Claws, Anal Sacs, and Ears. 7th editoin. [s.I.] : Elsevier Health Sciences, 2012. p. 724-773.

NUTTALL, T. Otitis. In: NOLI, C; COLOMBO, S. Feline Dermatology [s.l.] : Springer, 2020. p. 175-209.

VEIR, J. K. et al. Feline inflammatory polyps: Historical, clinical, and PCR findings for feline calici virus and feline herpes virus-l in 28 cases. Journal of Feline Medicine and Surgery, [S. I.], v. 4, n. 4, p. 195-199, 2002. DOI: 10.1053/jfms.2002.0172. 